\title{
Severe COVID-19 with acute respiratory distress syndrome (ARDS) in a sickle cell disease adult patient: case report
}

\author{
Marion Teulier ${ }^{*}$ (D), Alexandre Elabbadi ${ }^{1}$, Grigorios Gerotziafas ${ }^{2}$, François Lionnet ${ }^{3}$, Guillaume Voiriot ${ }^{1}$ \\ and Muriel Fartoukh ${ }^{1}$
}

\begin{abstract}
Background: Sickle-cell anaemia is a widespread genetic disease prevalent worldwide among African and AfricanAmerican populations. The pathogenesis is most often revealed by pulmonary conditions, including acute thoracic syndrome, which is affecting the life expectancy of these populations. The global spread of CoV2-SARS infection with a respiratory tropism, endothelial damages and procoagulant status endangers the SCD population. However, with only a few case reports, consequences of the Covid-19 pandemic on SCD population remain poorly known.
\end{abstract}

Case presentation: We report a case of a 33-year-old man with a history of homozygous SS homozygous sickle cell anemia who consulted on March 24, 2020 for febrile dyspnea 11 days after the onset of symptoms. A nasopharyngeal swab was positive for SARS-CoV-2. His respiratory status worsened rapidly in the emergency room and then in ICU leading to severe ARDS requiring intubation, curarization, and venovenous ECMO. Hematologically, severe hemolysis associated with major thrombocytopenia without documented spinal cord injury was noted. Several transfusion exchanges are performed. The evolution was finally slowly favorable and led to discharge from the intensive care unit and then from the hospital.

Conclusions: This case recalls the importance of an increased prevention policy against COVID-19among the SCD population. In addition, from a therapeutic point of view, it advocates (1) a high preventive anticoagulation from the outset according to the level of D-dimers (2) the use of venovenous ECMO in this particular case, whereas this technique has had rather disappointing results in acute chest syndromes. (3) Unexpectedly, our patient did not develop pulmonary arterial hypertension (PAH) and acute cor pulmonale (ACP), whereas this is a common feature of ARDS during SCD. These last two observations suggest a different pathophysiology of pulmonary disorders in SCD patients in the case of SARS COv2. It could be associated with marked hypoxemia secondary to pulmonary vascular vasodilation.

Keywords: Sickle cell disease, COVID-19, ARDS, ECMO, Case report

\footnotetext{
*Correspondence: marion.teulier@aphp.fr

${ }^{1}$ Sorbonne Université, Assistance Publique - Hôpitaux de Paris, Service

de médecine intensive réanimation, Hôpital Tenon, Paris, France

Full list of author information is available at the end of the article
}

\begin{abstract}
Background
Sickle cell disease (SCD) is a serious monogenic disorder that reduces life expectancy. The acute chest syndrome (ACS) is one of the most frequent condition requiring hospitalization in SCD patients, often with an infectious event as the initial cause, and the leading cause of death among SCD adult patients [1]. Consequences of the Covid-19 pandemic on SCD population remain poorly
\end{abstract}

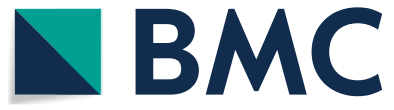

(c) The Author(s) 2021. Open Access This article is licensed under a Creative Commons Attribution 4.0 International License, which permits use, sharing, adaptation, distribution and reproduction in any medium or format, as long as you give appropriate credit to the original author(s) and the source, provide a link to the Creative Commons licence, and indicate if changes were made. The images or other third party material in this article are included in the article's Creative Commons licence, unless indicated otherwise in a credit line to the material. If material is not included in the article's Creative Commons licence and your intended use is not permitted by statutory regulation or exceeds the permitted use, you will need to obtain permission directly from the copyright holder. To view a copy of this licence, visit http://creativecommons.org/licenses/by/4.0/. The Creative Commons Public Domain Dedication waiver (http://creativeco mmons.org/publicdomain/zero/1.0/) applies to the data made available in this article, unless otherwise stated in a credit line to the data. 
known, with only a few case reports, including one nonsevere case in a 21-year-old man hospitalized with a history of SCD ( $\mathrm{HbS} / \beta 0$-thalassemia) on maintenance hydroxyurea therapy [2]; a series of four clinical cases of patients from 22 to 41 years old with ACS [3]; two cases of ACS [4]. Another case describes a patient with pneumonia and severe ACS successfully treated with Tocilizumab [5]. None of these patients was reported to develop acute respiratory distress syndrome (ARDS).

\section{Case presentation}

\section{Patient information}

A 33-year-old man with a history of SCD and moderate overweight (BMI, $28.4 \mathrm{~kg} / \mathrm{m}^{2}$ ) presented on March 24, 2020 to the Emergency Department of Tenon hospital (a referral SCD center in Paris, France), for a febrile dyspnea. Sickle cell homozygous disease (baseline hemoglobin $[\mathrm{Hb}$ ] value $11.5 \mathrm{~g} / \mathrm{dl}, \mathrm{HbF} 2.5 \%$, $\mathrm{HbS} 87 \%$ ) was known since childhood, and he had suffered mild episodes of vaso-occlusive crisis, and two episodes of ACS. Red blood cell transfusions had been required only once in the previous 20 years. Regular follow-up of SCD at our center had revealed early ophthalmological (Goldberg's stage III retinopathy) and renal (GFR $120 \mathrm{~mL} / \mathrm{min}$ and microabuminuria at $0.75 \mathrm{~g} / \mathrm{L}$ ) damage.

\section{Clinical findings}

The symptoms first appeared 11 days before admission with cough and headache. Then, he developed fever and dyspnea. In the Emergency Room, physical examination revealed fever $\left(39^{\circ} \mathrm{C}\right)$ and signs of acute respiratory distress (RR 36 cycles/min, room air pulse oximetry 88\%), without hemodynamic instability (BP $134 / 82 \mathrm{mmHg}$, HR $106 / \mathrm{min})$. The patient had no history of recent medication, he reported a contact with his sick girlfriend. Chest $\mathrm{X}$-ray showed bilateral alveolar and interstitial infiltrates predominating in the middle lobe (Fig. 1). Blood analysis revealed moderate anemia, reticulocytopenia, moderate hemolysis, lymphocytopenia and a major inflammatory syndrome (Table 1). Respiratory condition worsened rapidly requiring intensive care unit admission and intubation with mechanical ventilation.

\section{Diagnosis assessment and therapeutic intervention}

A nasopharyngeal swab was positive for SARS-CoV-2 at D1. Samples of respiratory tract secretions were taken on the admission day and a broad-spectrum empirical antibiotic therapy was initiated. The patient did not receive any experimental treatment specific to SARS-CoV-2.

Hemolysis worsened and prompted early blood exchange transfusions ( 3 sessions) for maintaining $\mathrm{HbS}$ value below $40 \%$. Bone marrow aspiration was performed on D3, because of a severe ACS associated with a drop in reticulocytes and a mild thrombocytopenia suggesting a spinal thrombosis. The bone marrow aspiration demonstrated normal structure and cytology without bone marrow necrosis. The PCR search for CMV, EBV, SARS-CoV and Parvovirus-B19 were negative. On D4, as D-dimer levels had increased markedly, anticoagulation was switched from prophylactic to therapeutic dosage (intravenous unfractionated heparin with a ratio of activated partial thromboplastin time target between 2 and 2.5). As shown in Table 1, this switch was associated with significant decrease of D-Dimers. In the acute phase, a search for thromboembolic events was done through a venous doppler ultrasound of the four limbs and a transthoracic cardiac ultrasound. This exploration was initially negative. Secondarily at the time of ECMO decanulation, in a septic context, cardiac ultrasound revealed a thrombus of the inferior vena cava. Fifteen days later, i.e. one month after admission, a thoracic angioscanner was performed, which no longer revealed this thrombus.

\section{Follow up and outcomes}

Despite neuromuscular blocking agents and repeated sessions of prone positioning, the respiratory condition progressed to severe COVID-19 with ARDS, with worsening pulmonary infiltrates (Fig. 1) and major

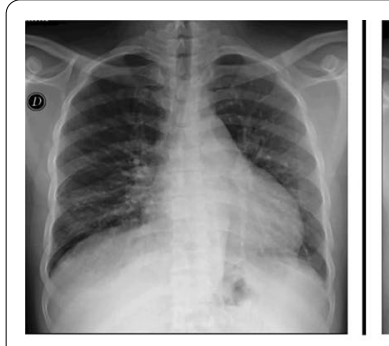

Chest X-ray (CXR) Baseline 2015

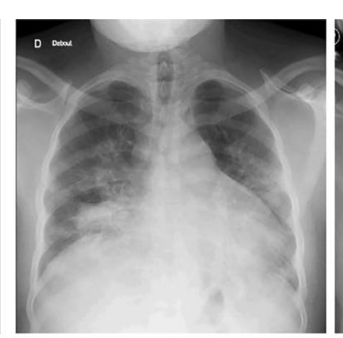

D0 - CXR ED admission

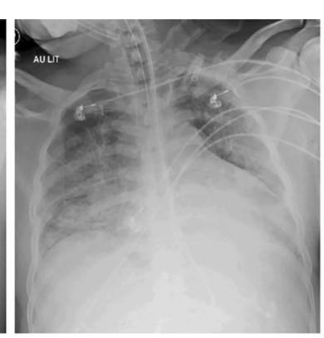

D1 - CXR ICU admission

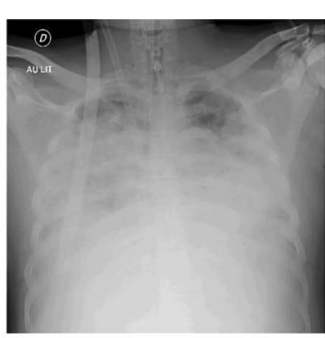

D5 - CXR initiation ECMO V/V

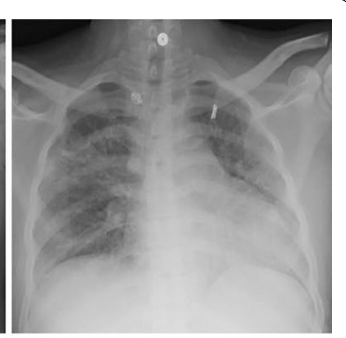

D27 - CXR ICU discharge

Fig. 1 Chest X-ray (CXR) evolution through hospitalization 
Table 1 Biology changes through hospitalization

\begin{tabular}{|c|c|c|c|c|c|c|c|}
\hline \multicolumn{2}{|l|}{ Day from admission } & \multirow{2}{*}{$\begin{array}{l}\text { D0 } \\
\text { ED admission }\end{array}$} & \multirow{2}{*}{$\begin{array}{l}\text { D1 } \\
\text { ICU admission }\end{array}$} & \multirow{2}{*}{$\begin{array}{l}\text { D5 } \\
\text { ECMO initiation }\end{array}$} & \multirow{2}{*}{$\begin{array}{l}\text { D15 } \\
\text { ECMO explantation }\end{array}$} & \multirow{2}{*}{$\begin{array}{l}\text { D27 } \\
\text { ICU discharge }\end{array}$} & \multirow{2}{*}{$\begin{array}{l}\text { D34 } \\
\text { Hospital } \\
\text { discharge }\end{array}$} \\
\hline Variables & Normal range & & & & & & \\
\hline \multicolumn{8}{|l|}{ Blood count } \\
\hline Hemoglobin (g/dL) & $12.0-18.0$ & 11.5 & 10.7 & 10.6 & 8.8 & 10.14 & 7.2 \\
\hline $\begin{array}{l}\text { Reticulocytes count } \\
(\times 10.9 / \mathrm{L})\end{array}$ & $25-125$ & 48 & 38 & 71 & 361 & 367 & 331 \\
\hline $\begin{array}{l}\text { White blood cell count } \\
(\times 10.9 / \mathrm{L})\end{array}$ & $4.0-10.0$ & 10.5 & 13.86 & 43.29 & 16.37 & 10.14 & 14.79 \\
\hline Neutrophils (× 10.9/L) & $1.7-7.0$ & 9.44 & 12.29 & 31.64 & 11.63 & 5.57 & 9.73 \\
\hline Lymphocytes (× 10.9/L) & $1.5-4.0$ & 0.71 & 0.98 & 3.18 & 2.56 & 3,17 & 3.03 \\
\hline Platelets (× 10.9/L) & $150-400$ & 171 & 182 & 203 & 195 & 367.2 & 228 \\
\hline \multicolumn{8}{|l|}{ Inflam } \\
\hline $\mathrm{C}$ reactive protein $\mathrm{mg} / \mathrm{L}$ & $<5.0$ & 300.9 & 343.6 & 303.7 & 160.1 & 63.3 & 20.2 \\
\hline Procalcitonin $\mu \mathrm{g} / \mathrm{L}$ & $<0.5$ & & 1.78 & 1.56 & 0.38 & 0.59 & \\
\hline \multicolumn{8}{|l|}{ Hemostasis } \\
\hline PT (\%) & $>70$ & & 75 & 78 & 83 & 71 & \\
\hline Fibrinogen (g/L) & $1.80-4.0$ & & 9.4 & 7.8 & 6.4 & 6.0 & \\
\hline D-dimers (ng/mL) & $<500$ & & 3030 & 947 & $>20,000$ & 2379 & \\
\hline \multicolumn{8}{|l|}{ Hemolysis } \\
\hline ASAT (IU/L) & $<35$ & & 27 & 464 & 64 & 55 & \\
\hline ALAT (IU/L) & $<43$ & & 9 & 235 & 47 & 39 & \\
\hline $\begin{array}{l}\text { Serum lactate dehydroge- } \\
\text { nase (IU/L) }\end{array}$ & $125-250$ & 393 & 438 & 2498 & 1044 & 709 & \\
\hline Total bilirubin ( $\mu \mathrm{mol} / \mathrm{L})$ & $<17$ & & 24 & 20 & & 25 & \\
\hline
\end{tabular}

hypoxemia $\left(\mathrm{PaO}_{2} / \mathrm{FiO}_{2}\right.$ ratio of 54 with PEEP $10 \mathrm{cmH} 20$ and $\left.\mathrm{FiO}_{2} 100 \%\right)$. There were no acute cardiac nor pulmonary vascular dysfunction (explored by repeated transthoracic cardiac ultrasound). Giving this refractory ARDS situation, a venovenous extracorporeal membrane oxygenation (ECMO) was installed on D5. Because of a significant increase in inflammatory markers, and clinical and radiographic degradation, we searched for respiratory infection and we maintained concomitantly a probabilistic antibiotic treatment.

A bronchoalveolar lavage (BAL) was performed on D9 to rule out bacterial infection or fat embolism (54 $\mathrm{mL}$ recovered from $150 \mathrm{~mL}$ instilled) revealing lymphocytic alveolitis $(640,000$ cells with $50 \%$ macrophages, 36\% lymphocytes, and $13 \%$ polymorphonuclears). The bacterial culture and the search for other viruses were negative. Blood cultures and local samples from the catheterization were negative. Antibiotic prophylaxis was suspended on D10. Secondarily to an increase in inflammatory markers and clinical deterioration, a protected distal sampling allowed the diagnosis of pneumopathy acquired under late mechanical ventilation (E. Coli and E. Cloacae), treated with the adapted antibiotics at D16.
The evolution was then slowly favorable, allowing the ECMO to be withdrawn after 10 days. The patient was extubated at D25. A laryngeal edema complicated the extubation and was treated with corticosteroid aerosol, without systemic corticotherapy and quickly resolved. Following the extubation, we did not perform non-invasive ventilation or high flow oxygen therapy. Finally, the patient was discharged from ICU on D27 and then from hospital on D34 days after his admission.

\section{Discussion and conclusions}

The SCD population represents several million people worldwide, while there is no epidemiological data specific to this population regarding SARS-CoV-2. Although its pathophysiology and epidemiology differ from those of the H1N1 influenza epidemic, it should be recalled that in SCD patients, the severity of the infection was much greater than in the general population [6] (17\% rate of hospitalization in ICU, the vast majority of whom had ARDS). The SCD population is thus likely an at-risk population regarding the Covid 19.

Distinctive features of Covid 19 appear to include endothelial damage and procoagulant status [7-9]. Indeed, Varga et al. [9] have described a shift in the vascular equilibrium with endothelitis with lymphocytic 
infiltration and subsequent ischemia associated with a procoagulant state, particularly in high-risk ethnicity, such as African-Americans [10]. Sickle cell patients constitutionally suffer from small vessel vasculopathy. Therefore, the SCD population seems particularly at risk of developing very severe pulmonary vascular damage during SARS-CoV-2 infection.

Experience with ECMO in SCD patients with ARDS has been disappointing so far, with a case-fatality rate of $73 \%$ [11]. The survival in our patient despite criteria for severe ARDS and refractory hypoxemia suggest that ECMO should still be considered in such patients, and that the damages associated with COVID-19 differ from ARDS due to other causes, especially ACS in SCD patients. Fogarty et al. [12] suggested that a specific phenotype of refractory ARDS caused by COVID-19 was associated with concurrent 'double-hit' pathologies targeting both ventilation and perfusion within the lungs through the involvement of ACE2 receptors present in type II pneumocytes and vascular endothelial cells.

It is noteworthy that our patient did not develop pulmonary arterial hypertension (PAH) and acute cor pulmonale (ACP), whereas this is a common feature of ARDS during SCD [13-15]. For example, Cechini et al. [13] recently reported that $100 \%$ such patients had PAH and $90 \%$ had ACP. Several echocardiographies have been performed throughout the evolution of our patient, showing no evidence of acute PAH. The lack of ACP in our patient may be related to the pathophysiology of COVID-19 and associated marked hypoxemia secondary to pulmonary vascular vasodilation [16]. Given the recorded frequency of pulmonary artery thrombosis associated with COVID-19 [17], therapeutic anticoagulation may also have contributed to a protective effect on the occurrence of ACP in our patient.

To date, there are only scarce reports of COVID-19 in SCD patients. Meanwhile, it is essential to stress the importance of increased awareness and effective preventive measures in these particular high-risk patients. The risk is indeed greater because of the increased susceptibility and severity of respiratory tropism infections but also because of the procoagulant endothelitis of the Covid-19. Therefore, compliance with preventive precautions (masks, social distancing, hand hygiene inparticular).

In terms of therapeutic intervention, early care, early blood exchanges and high preventive anticoagulation should be provided in these patients. Interestingly, ECMO should be considered and may be more effective than ACS related ARDS, due to a different pathophysiology of Covid-19 infection.

\section{Abbreviations}

SCD: Sickle cell disease; ACS: Acute chest syndrome; ARDS: Acute respiratory distress syndrome; ECMO: Extracorporeal membrane oxygenation; BAL: Bronchoalveolar lavage; ICU: Intensive care unit; PAH: Pulmonary arterial hypertension; ACP: Acute Cor Pulmonale; D: Day; ED: Emergency department; Inflam: Inflammation.

\section{Acknowledgements}

Not applicable.

\section{Authors' contributions}

Each of the authors confirms that this manuscript has not been previously published and is not currently under consideration by any other journal. Additionally, all of the authors have approved the contents of this paper and have agreed to BMC pulmonary medicine journals submission policies. MT wrote the manuscript, designed the figure and table with input from all authors. AE discussed the results and made numerous revisions on the initial manuscript. He also participated in the data collection and participated in the corrections requested by the reviewers. GG encouraged MT to investigate haematological and especially endothelial damages in the pathogenesis of Covid-19 infection in this patient. He proofread the hematology section and made substantial comments. FL provided his expertise on sickle cell disease patients and blood exchanges. He proofread the introduction and conclusion and made substantial comments especially on the introduction and conclusion. $F L, A E$, GV and MF actively participated in the therapeutic choices for this patient. MF brought his experience on the management of ACS-related severe ARDS, including the use of venovenous ECMO and specific complications. GV, AE et MF substantially contributed to the writing of this manuscript by proofreading it, guiding MT in her writing and providing numerous comments. All authors discussed the results and contributed to the final manuscript. All authors provided critical feedback and helped shape the research, analysis and manuscript. All authors approved the submitted the final version. They also have agreed both to be personally accountable for the author's own contributions and to ensure that questions related to the accuracy or integrity of any part of the work were appropriately investigated. All authors read and approved the final manuscript.

\section{Funding}

We received no funding for this publication.

\section{Availability of data and materials}

All raw data (chest X-rays, biological data) are available on the APHP computer system (via a software called Orbis not remotely accessible without privileged access) and can be provided on request by the corresponding author.

\section{Ethics approval and consent to participate}

The patient's written consent has been obtained for this publication. No ethics approval needed since it is a case report.

\section{Consent for publication}

The patient's written consent has been obtained for this publication.

\section{Competing interests}

To the best of our knowledge, the named authors have no competing interests, financial or otherwise.

\section{Author details \\ ${ }^{1}$ Sorbonne Université, Assistance Publique - Hôpitaux de Paris, Service de médecine intensive réanimation, Hôpital Tenon, Paris, France. ${ }^{2}$ Sorbonne Université, Assistance Publique - Hôpitaux de Paris, Unité d'Explorations Fonctionnelles et Génétiques du Risque Vasculaire, Consultation Thrombose - Oncologie, Hôpital Tenon, Paris, France. ${ }^{3}$ Sorbonne Université, Assistance Publique - Hôpitaux de Paris, Service de médecine interne, Hôpital Tenon, Paris, France.}

Received: 17 July 2020 Accepted: 14 January 2021

Published online: 29 January 2021 


\section{References}

1. Vichinsky EP, Neumayr LD, Earles AN, et al. Causes and outcomes of the acute chest syndrome in sickle cell disease. National Acute Chest Syndrome Study Group. N Engl J Med. 2000;342(25):1855-65. https://doi. org/10.1056/NEJM200006223422502.

2. Beerkens F, John M, Puliafito B, Corbett V, Edwards C, Tremblay D. COVID19 pneumonia as a cause of acute chest syndrome in an adult sickle cell patient. Am J Hematol. 2020. https://doi.org/10.1002/ajh.25809.

3. Hussain FA, Njoku FU, Saraf SL, Molokie RE, Gordeuk VR, Han J. COVID-19 infection in patients with sickle cell disease. Br J Haematol. 2020. https:// doi.org/10.1111/bjh.16734.

4. Nur E, Gaartman AE, van Tuijn CFJ, Tang MW, Biemond BJ. Vaso-occlusive crisis and acute chest syndrome in sickle cell disease due to 2019 novel coronavirus disease (COVID-19). Am J Hematol. 2020;95:725-6. https:// doi.org/10.1002/ajh.25821.

5. De Luna G, Habibi A, Deux JF, et al. Rapid and severe covid-19 pneumonia with severe acute chest syndrome in a sickle cell patient successfully treated with tocilizumab. Am J Hematol. 2020. https://doi.org/10.1002/ ajh. 25833 .

6. Strouse JJ, Reller ME, Bundy DG, et al. Severe pandemic H1N1 and seasonal influenza in children and young adults with sickle cell disease. Blood. 2010;116(18):3431-4. https://doi.org/10.1182/blood-2010-05282194.

7. Giannis D, Ziogas IA, Gianni P. Coagulation disorders in coronavirus infected patients: COVID-19, SARS-CoV-1, MERS-CoV and lessons from the past. J Clin Virol. 2020;9(127):104362. https://doi.org/10.1016/j. jcv.2020.104362.

8. Escher R, Breakey N, Lämmle B. Severe COVID-19 infection associated with endothelial activation. Thromb Res. 2020;15(190):62. https://doi. org/10.1016/j.thromres.2020.04.014.

9. Varga Z, Flammer AJ, Steiger P, et al. Endothelial cell infection and endotheliitis in COVID-19. Lancet. 2020. https://doi.org/10.1016/S0140 $-6736(20) 30937-5$.
10. White $\mathrm{RH}$, Keenan CR. Effects of race and ethnicity on the incidence of venous thromboembolism. Thromb Res. 2009;123(Suppl 4):S11-17. https //doi.org/10.1016/S0049-3848(09)70136-7.

11. Boissier F, Bagate F, Schmidt M, et al. Extracorporeal life support for severe acute chest syndrome in adult sickle cell disease: a preliminary report. Crit Care Med. 2019;47(3):e263-5. https://doi.org/10.1097/CCM.00000 00000003628.

12. Fogarty H, Townsend L, Ni Cheallaigh C, Bergin C, Martin-Loeches I, Browne P, Bacon CL, Gaule R, Gillett A, Byrne M, Ryan K, O'Connell N, O'Sullivan JM, Conlan N, O'Donnell JS. COVID-19 Coagulopathy in Caucasian patients. Br J Haematol. 2020. https://doi.org/10.1111/bjh.16749.

13. Cecchini J, Boissier F, Gibelin A, et al. Pulmonary vascular dysfunction and cor pulmonale during acute respiratory distress syndrome in sicklers. Shock. 2016;184:1022-9. https://doi.org/10.1097/SHK.000000000000064 0 .

14. Mekontso-Dessap A, Leon R, Habibi A, Nzouakou R, et al. Pulmonary hypertension and cor pulmonale during severe acute chest syndrome in sickle cell disease. Am J Respir Crit Care Med. 2008;177:646-53. https:// doi.org/10.1164/rccm.200710-16060C.

15. Mekontso-Dessap A, Deux JF, Abidi N, et al. Pulmonary artery thrombosis during acute chest syndrome in sickle cell disease. Am J Respir Crit Care Med. 2011;184:1022-9. https://doi.org/10.1164/rccm.201105-07830C.

16. Gattinoni L, Chiumello D, Caironi P, et al. COVID-19 pneumonia: different respiratory treatments for different phenotypes? Intensive Care Med. 2020. https://doi.org/10.1007/s00134-020-06033-2.

17. Klok FA, Kruip MJHA, van der Meer NJM, et al. Incidence of thrombotic complications in critically ill ICU patients with COVID-19. Thromb Res. 2020. https://doi.org/10.1016/j.thromres.2020.04.013.

\section{Publisher's Note}

Springer Nature remains neutral with regard to jurisdictional claims in published maps and institutional affiliations.
Ready to submit your research? Choose BMC and benefit from:

- fast, convenient online submission

- thorough peer review by experienced researchers in your field

- rapid publication on acceptance

- support for research data, including large and complex data types

- gold Open Access which fosters wider collaboration and increased citations

- maximum visibility for your research: over 100M website views per year

At BMC, research is always in progress.

Learn more biomedcentral.com/submissions 